\title{
AN ATTEMPT TO USE FUNCTIONAL DIVERSITY INDICES FOR THE ASSESSMENT OF WEED COMMUNITIES
}

\author{
Magdalena Jastrzębska, Maria Wanic, Marta K. Kostrzewska, \\ Kinga Treder, Janusz Nowicki
}

\author{
University of Warmia and Mazury, Department of Agricultural Systems, \\ Plac Łódzki 3, 10-718 Olsztyn, Poland \\ e-mail: jama@uwm.edu.pl; mwanic@uwm.edu.pl; marta.kostrzewska@uwm.edu.pl; kinga.treder@uwm.edu.pl
}

Received: 26.05.2011

\begin{abstract}
This paper presents an analysis of changes in functional diversity of weeds in spring barley grown in the period 19902004 in crop rotation after potato with a 25\% share of this cereal (potato - spring barley - field pea - winter triticale) as well as in crop rotation with its $75 \%$ share (potato - spring barley - spring barley - spring barley) in which barley was grown once and twice after the same barley crop. No weed control was used in the present experiment. Every year in the spring (at full emergence of barley) and before harvest, the species composition and numbers of individual weed species were determined, as well as their weed biomass before harvest. On this basis, the selected functional diversity indices were calculated. Multidimensional techniques were used for dividing weeds into functional groups and for the determination of some of the indices. Potato/barley crop rotation with a $25 \%$ share of barley and growing spring barley once and twice after the same barley crop did not differentiate weed functional biodiversity.

The weed functional diversity indices showed different variations over time. Higher variation was usually observed for the indices calculated for the summer communities compared to the spring ones. The strength and significance of the positive correlation between weed functional diversity and precipitation in the growing season and of the negative correlation with mean temperature for the period from April to August were dependent on the measure of diversity. The functional diversity indices showed high convergence. The FD and FAD indices proved to be interchangeable.
\end{abstract}

Key words: weeds, functional diversity, functional groups, functional diversity indices, spring barley, crop rotation

\section{INTRODUCTION}

More and more attention is devoted to weed biodiversity. A special group focused on this issue
(Weeds and Biodiversity Working Group) has been established within the European Weed Research Society (EWRS). The number of publications on this subject is also growing. So far, most of them have referred to weed species diversity. Its common measure is the number of species (B l e c h a r c z y k et al. 2000; L o s o s ová et al. 2004; K a a r and Freyer, 2008). Measures that take into account the quantitative proportions between species such as the Shannon-Wiener index, for example, are also used more and more frequently (S teven sen et al. 1997; J ę dru s zczak and Antoszek, 2004; J a strzęb sk a et al. 2006; Feledyn-Szewczyk, 2008). These measures treat equally all species present in a community, irrespective of the role played by them in the ecosystem. Only the relative abundance of each species determines its importance (Magurran, 2005; Mouchet et al. 2010).

Functional diversity offers a different look at this issue. It is understood through the concept of ecological niche that describes comprehensively the role of an organism in the biocoenosis, taking into account its food relationships, habitat preferences and adaptations, life forms and strategies, intra- and interspecific interactions, underlying processes, etc. (E1ton, 1927). It is thus based on organisms' traits that influence the functioning of the ecosystem (Til ma n, 2001). Species that have a similar effect on a particular process (processes) in the ecosystem or are characterized by a similar response to environmental conditions are grouped into the so-called functional groups ( $\mathrm{H} \mathrm{o}$ o p e r et al. 2002). Functional groups of organisms are defined on the basis of one trait (S c r o s a ti et al. 2010) or many traits (W a l ker and Langridge, 2002). The number of functional groups and species 
richness of each group are a common measure of functional diversity (Tilman, 2001; Scrosati et al. 2010). The Simpson and Shannon-Wiener diversity indices, based on the proportions of abundance of functional groups (D e vin et al. 2005; S c r o s a ti et al. 2010), and formulas referring to cluster analysis ( $\mathrm{P} \mathrm{e} \mathrm{t}$ che y and Gas to n, 2002) are also used. In functional diversity assessment, an essential problem is how many traits and which traits should be taken into account, how to standardize the method of expression of these traits, and how to incorporate species abundances (Petchey and Gaston, 2006). Trait selection is usually arbitrary, which is considered to be a weakness of this concept (P e tche y and Gas t o n, 2002).

In the last decade, many papers on functional diversity have appeared in the world literature ( $\mathrm{Pet}$ chey and Gaston, 2006; Schleuter et al. 2010), also including those relating to functional diversity of plant communities ( $\mathrm{Diaz}$ and $\mathrm{Cabido}$, 2001; W alker and Langridge, 2002; de Bello et al. 2006; L e p š et al. 2006; B i w a s and M a llik, 2010). Nevertheless, there are still relatively few articles that deal with weed communities ( $\mathrm{L}$ e m e r le et al. 2004; P u ri ce $11 \mathrm{i}$ and T u e s c a, 2005; S torke y, 2006; S ing h et al. 2008).

The aim of this paper is to test several functional diversity indices in terms of the possibility of using them in the assessment of field weed communities.

\section{MATERIALS AND METHODS}

The data forming the basis for this paper originate from a strictly controlled, static field experiment carried out in the period 1990-2004 at the Bałcyny Production and Experimental Station $\left(\mathrm{N}=53^{\circ} 3549\right.$, $\mathrm{E}=19^{\circ} 5120.3$ ). The experiment was established on typical grey-brown podzolic soil derived from light silty loam, included in the soil category of medium soils, with a humus content in the topsoil from 1.49 to $1.61 \%$ and with medium macro- and micronutrient availability in the soil. The objects of the study were weed communities in spring barley (Hordeum vulgare L.), grown in two crop rotations with a $25 \%$ and $75 \%$ share of this cereal:

$$
\begin{aligned}
\text { A }- & 25 \% \text { : potato - spring barley }- \text { field pea - } \\
& \text { winter triticale; } \\
\text { B }-75 \% \text { : potato - spring barley - spring barley } & \\
& - \text { spring barley. }
\end{aligned}
$$

The experiment was set up in a randomized block design with four replications. The total number of plots was 32, and the area of a single plot $-20 \mathrm{~m}^{2}$.

Three crop rotation fields sown with barley were chosen for the study, notably: crop rotation A - after potato (potentially the best crop stand - A-p), and crop rotation $\mathrm{B}$ where barley was grown once $(\mathrm{B}-\mathrm{b})$ and twice (B-bb) after the same barley crop, that is, for the second and third time, respectively, in the same field.

No weed control was used in the experiment (throughout its whole duration) in order to make the role of the forecrop itself more evident.

Weed infestation of spring barley was determined each year in the spring (at full emergence of the cereal crop) and before harvest, in duplicate in each plot, by determining weed density and species composition at designated fixed sites $\left(1 \mathrm{~m}^{2}\right)$. In the case of monocotyledonous weeds, the number of stems was counted in the analysis performed before harvest. During this second analysis, weed biomass (air-dry weight) was also determined with a breakdown into individual species.

Detailed information on the experimental conditions can be found in the paper of $\mathrm{W}$ a n i c et al. (2010). The results on weed species composition and density in spring barley (in the spring and before harvest) as well as the results on biomass (before harvest) were used to calculate several selected functional diversity indices: FR ( $\mathrm{Tilm}$ a n, 2001, see also: $\mathrm{Ri}$ c ott a , 2005), FD (P e tchey and G a s to n, 2002), FAD (W a lker et al. 1999), H' (S h a n n o n, 1948; Wien e r, 1948), Q (R a o, 1982; M o u c het et al. 2010). They were calculated for the communities from each crop stand (crop rotation-forecrop), year, and time of determination.

FR (functional richness) means the number of functional groups in a weed community. Functional groups were distinguished on the basis of three arbitrarily chosen functional traits:

- the belonging to a biological group according to the growth cycle (D o m a ń s k a , 1997);

- the most frequently occupied layer in the cereal crop (D o m a ń s k a , 1997);

- the ecological indicator value expressed as the soil trophic state index $(\mathrm{Tr})$ according to Zarzy cki et al. (2002).

All weed species that appeared in the barley crop during the study period were included in the classification. On the basis of cluster analysis, they were divided into 5 theoretical groups by grouping these species using k-means clustering. The species composition of the particular groups is presented in Table 1. The Latin nomenclature of weed species follows $\mathrm{Mi}$ re k et al. (1995). Species richness of the actual groups in the communities is also presented.

FD (functional diversity) is equal to the sum of the branch lengths of a dendrogram constructed by cluster analysis on the basis of the traits forming the basis for dividing the species into functional groups. The agglomeration of species was performed by Ward's method, using the Euclidean distance as a measure of dissimilarity between them. An example of calculation of FD is shown in Fig. 1. 
The other indices were calculated in accordance with the below formulas.

FAD (functional attribute diversity): $\mathrm{FAD}=\sum_{i=1}^{S} \sum_{j=1}^{S} d_{i j}$

Q (Rao's quadratic entropy): $\mathrm{Q}=\sum_{i=1}^{S-1} \sum_{j=i+1}^{S-1} d_{i j} p_{i} p_{j}$

$\mathrm{H}$ (Shannon-Wiener's entropy): $\mathrm{H}=\sum_{x=1}^{F R}\left(p_{x} \ln p_{x}\right)$ where:

$S$ - the number of species in the community;

$d_{i j}-$ dissimilarity between species $i$ and $j$, measured by the Euclidean distance;

$F R$ - the number of functional groups in the community;

$p_{x}-$ the proportion of density or biomass of the $x$ th functional group in the community to the sum of weed densities or biomass of all groups; $p_{i}-$ the proportion of density or biomass of the $i$ th species in the community to the sum of densities or biomass of all species;

$p_{j}-$ the proportion of density or biomass of the $j$ th species in the community to the sum of densities or biomass of all species.

Variations in the indices between years are presented in the form of variation range (min.-max.), coefficient of variation, and trends over time. The trends of the indices over time are illustrated by showing the direction and significance of the linear trend. Correlations between the functional diversity indices, on the one hand, and precipitation and mean temperature in the study period, on the other hand, were determined by means of coefficients of linear correlation. The relationships between the indices are presented in the form of matrix scatterplots, together with the fitting of the scatter of points to the linear function. The strength of the relationships is expressed by the size and significance of the correlation coefficients.

The calculations were made using STATISTICA software.

Table 1.

Division of weed species infesting spring barley in the period 1990-2004 into functional groups

\begin{tabular}{|c|c|}
\hline Functional group & Weed species in the group \\
\hline group 1 & $\begin{array}{l}\text { Anchusa arvensis } \\
\text { Apera spica-venti } \\
\text { Conyza canadensis } \\
\text { Crepis tectorum } \\
\text { Galium aparine } \\
\text { Matricaria maritima ssp. inodora } \\
\text { Papaver rhoeas } \\
\text { Vicia hirsuta } \\
\text { Viola arvensis } \\
\end{array}$ \\
\hline group 2 & $\begin{array}{l}\text { Avena fatua } \\
\text { Chenopodium album } \\
\text { Cirsium arvense } \\
\text { Fallopia convolvulus } \\
\text { Polygonum lapathifolium ssp. lapathifolium } \\
\text { Raphanus raphanistrum } \\
\text { Sinapis arvensis } \\
\text { Sonchus arvensis }\end{array}$ \\
\hline group 3 & $\begin{array}{l}\text { Capsella bursa-pastoris } \\
\text { Fumaria officinalis } \\
\text { Lamium amplexicaule } \\
\text { Myosotis arvensis } \\
\text { Poa annua } \\
\text { Thlaspi arvense } \\
\text { Veronica arvensis }\end{array}$ \\
\hline group 4 & $\begin{array}{l}\text { Arenaria serpyllifolia } \\
\text { Erodium cicutarium } \\
\text { Myosurus minimus } \\
\text { Polygonum aviculare } \\
\text { Spergula arvensis }\end{array}$ \\
\hline group 5 & $\begin{array}{l}\text { Echinochloa crus-galli } \\
\text { Equisetum arvense } \\
\text { Galeopsis tetrahit } \\
\text { Galinsoga parviflora } \\
\text { Plantago major } \\
\text { Stellaria media }\end{array}$ \\
\hline
\end{tabular}




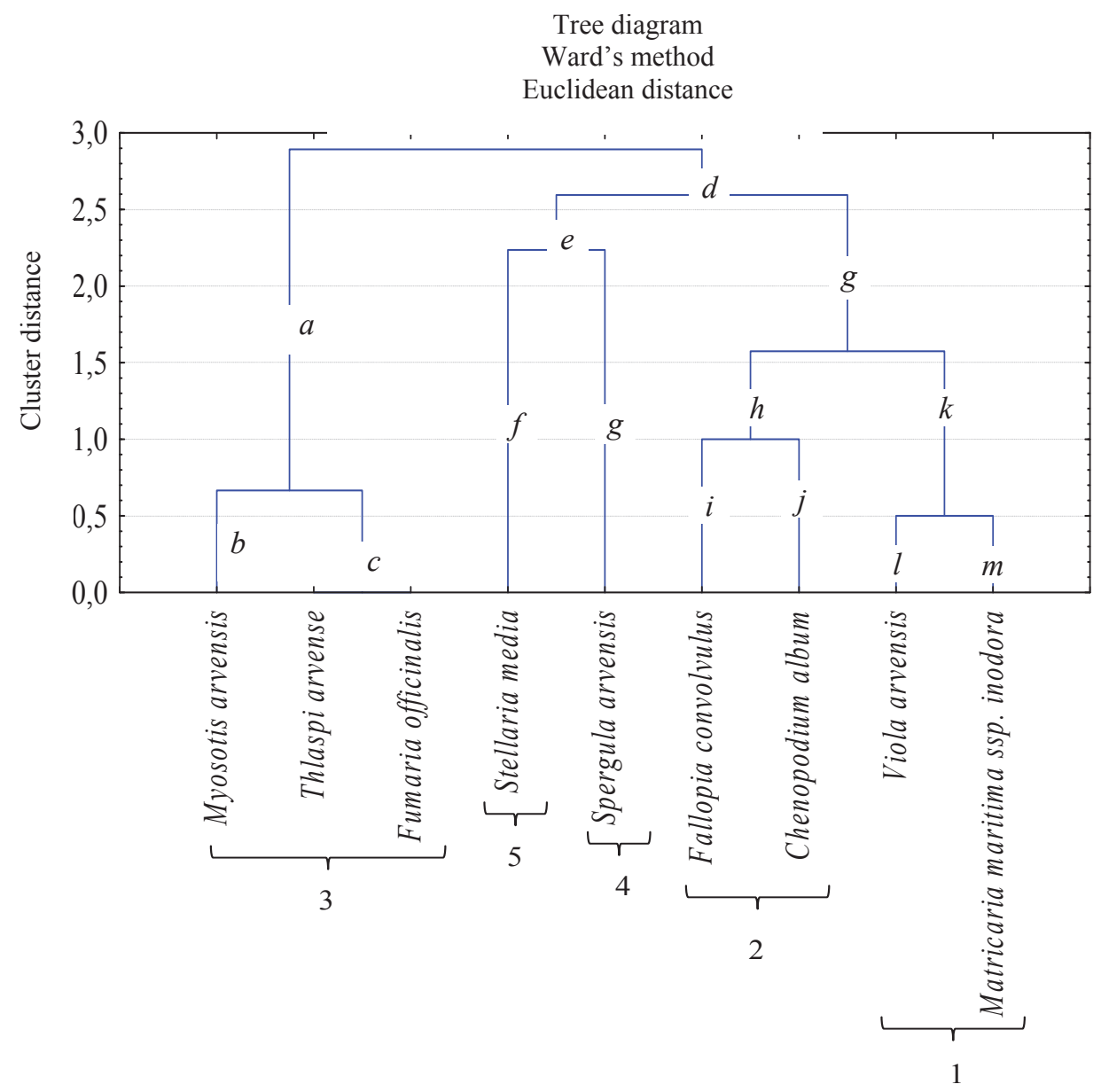

Fig. 1. An example of calculation of the sum of the branch lengths of a dendrogram constructed on the basis of the functional traits for the weed community developed in the spring of 1990 in barley grown in crop rotation A after potato (A-p); the sum of the values corresponding to the branch lengths $a-m$ (here: measured by the Euclidean distance) is equal to the value of the FD index $(\mathrm{FD}=14.4) ; 1-5$ - functional groups in the community according to the classification presented in Table 1.

\section{RESULTS}

A detailed analysis of weed density and biomass can be found in the paper by W a nic et al. (2010). Over the 15-year study period, weed density was $72-584 \mathrm{pcs} \times \mathrm{m}^{-2}$ in the spring, whereas before harvest 58-450 $\mathrm{pcs} \times \mathrm{m}^{-2}$, and it did not depend on the barley stand in the crop rotation. Weed biomass was in the

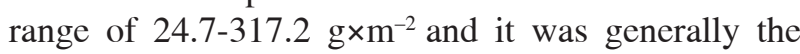
lowest in the stand following a potato crop (A) and increased along with the deterioration of the crop stand, that is, when barley was grown in crop rotation with a $75 \%$ share of this cereal (B), first after the same barley crop and then for the third time in the same field. Weed density and biomass showed high variations between years as well as a positive correlation with precipitation and a negative correlation with temperature in the study period.

Functional diversity of weeds in the spring barley crop, expressed by means of various indices, was not differentiated by the conditions that were created for the segetal vegetation by growing this cereal in crop rotation. This applies both to the time of determination in the spring and the status before harvest (Table 2). Potato/barley crop rotation with a $25 \%$ share of this cereal (A-p) as well as growing barley once and twice after the same barley crop proved to be insufficiently contrasted to affect the trait in question of the weed communities. The functional diversity indices exhibited greater variation over time. However, it was significant that the ranges and coefficients of variation of the individual indices were similar for the three crop stands under investigation. Higher variation was usually observed for the indices calculated for the summer communities compared to those determined for their spring equivalents.

Irrespective of time of analysis and crop stand, the lowest coefficients of variation were calculated for FR. In the spring, representatives of all the five or only four designated functional groups appeared, whereas before harvest functional richness decreased, sometimes even to three groups. As a result of that, the coefficients of variation were determined in the range of 11.4-16.7. 
The full theoretical species representation of the actual groups was not found in any year, stand or time of determination (Fig. 2). The number of species representing the individual groups was variable, ranging from 0 to 6 taxa. Groups 1, 2, and 3 were usually represented by at least one species every year (an exception: the year 1992 before harvest in the stand A-p). Group 4 was the group that did not appear most frequently in the actual communities in the spring and before harvest (it was not represented by any species).

The index FAD showed the highest variation between years (Table 2). The large amplitude between the minimum and maximum of its value (the largest one 14-644 in the stand B-p before harvest) and the high coefficients of variation for the stands and times of determination (67.3-95.5\%) were to a large extent a derivative of the applied procedure.

In the case of the spring communities that developed in the stands B-b and B-bb, the values of the FD and FAD indices represented an increasing linear sequence, which was statistically confirmed (Table 2). The significance of the linear trends over years was not demonstrated for FR and for the indices weighted with weed density $\left(\mathrm{H}_{\text {density }}\right.$ and $\left.\mathrm{Q}_{\text {density }}\right)$. In the case of the summer time of determination, the indices based only on species composition generally showed an increasing linear trend over time (an exception is FR for the stand B-b), while the trends of the indices that incorporated weed abundance (density or biomass) usually did not find confirmation (an exception is $\mathrm{Q}_{\text {biomass }}$ for the stand $\mathrm{B}-\mathrm{bb}$ ).

Table 2.

Functional diversity indices for weeds in the spring barley crop and their variations expressed by means of simple statistics

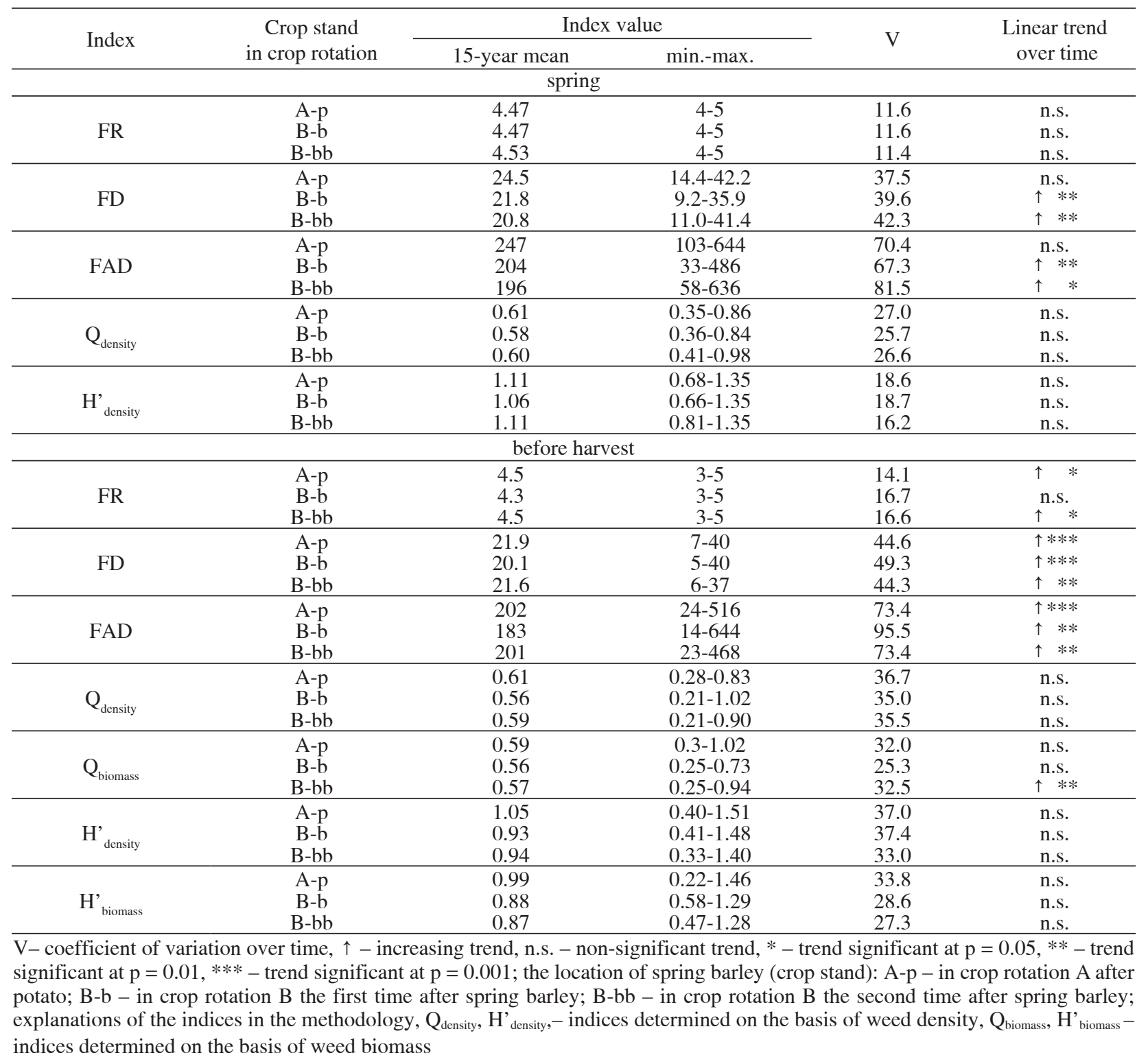




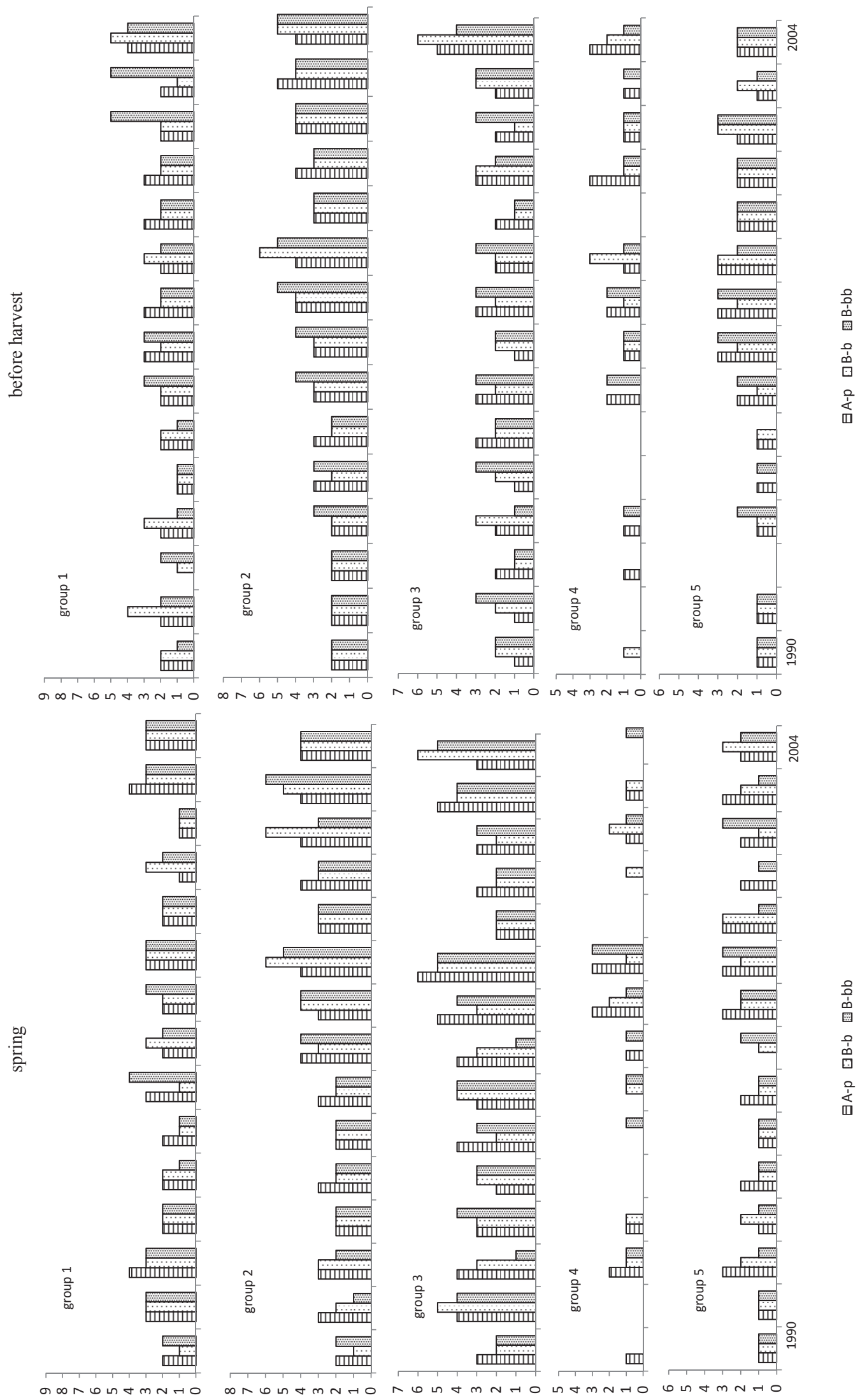

Fig. 2. Species richness of functional groups in the weed communities in spring barley; the location of spring barley (crop stand): A-p - in crop rotation A after potato; B-b - in crop rotation B the first time after spring barley; B-bb - in crop rotation B the second time after spring barley. 
Weed functional diversity was mainly positively correlated with precipitation in the growing season and negatively with temperature, but the strength and significance of these relationships were different depending on the measure of diversity and conditions in particular months (Table 3). The indices FD, FAD, and $\mathrm{Q}_{\text {density }}$ showed a significant positive correlation with total rainfall in April, at the same time being weakly correlated with temperature in this month. None of the indices exhibited a significant dependence on rainfall and thermal conditions in May, while in June only FR was significantly positively correlated with precipitation. The higher temperature in July had a significant effect on the decrease in weed functional diversity before harvest, as measured by the indices incorporating species abundance $\left(\mathrm{Q}_{\text {density }}, \mathrm{Q}_{\text {biomass }}, \mathrm{H}_{\text {density }}, \mathrm{H}_{\text {biomass }}\right)$. All the indices analysed in the summer period, except for the index based on the Shannon-Wiener formula (H'), were significantly negatively correlated with August temperature, irrespective of the method of expression of abundance. All the diversity indices in question were negatively correlated with mean temperature for the period from April to August (a significant correlation). In turn, FR and $\mathrm{Q}_{\text {density }}$ showed a confirmed positive relationship with total rainfall during the growing season.

The study demonstrates (Figs 3 and 4) that the weed functional diversity indices in question showed high convergence, which in most cases was confirmed by the size and significance of the coefficients of linear correlation at both times of determination. The FD and FAD indices proved to be almost completely interchangeable (at both times of determination $r>0.90$ ). This is probably attributable to the procedural similarity, since both these indices are based on interspecific divergence measured by the same measure (here: Euclidean distance). The indices $\mathrm{H}_{\text {density }}$ and $\mathrm{Q}_{\text {density }}$ as well as FAD and $\mathrm{Q}_{\text {density }}$ for the spring time of determination exhibited a strong correlation $(\mathrm{r} \leq 0.80$; $\mathrm{p} \geq 0.001$ ), while among the indices determined for the summer period, these were the following, respectively: $\mathrm{Q}_{\text {density }}$ and $\mathrm{Q}_{\text {biomass }}(\mathrm{r}=0.88), \mathrm{H}_{\text {density }}$ and $\mathrm{Q}_{\text {density }}$ $(\mathrm{r}=0.86), \mathrm{H}_{\text {density }}^{\prime}$ and $\mathrm{H}^{\prime}$ biomass $(\mathrm{r}=0.80)$.
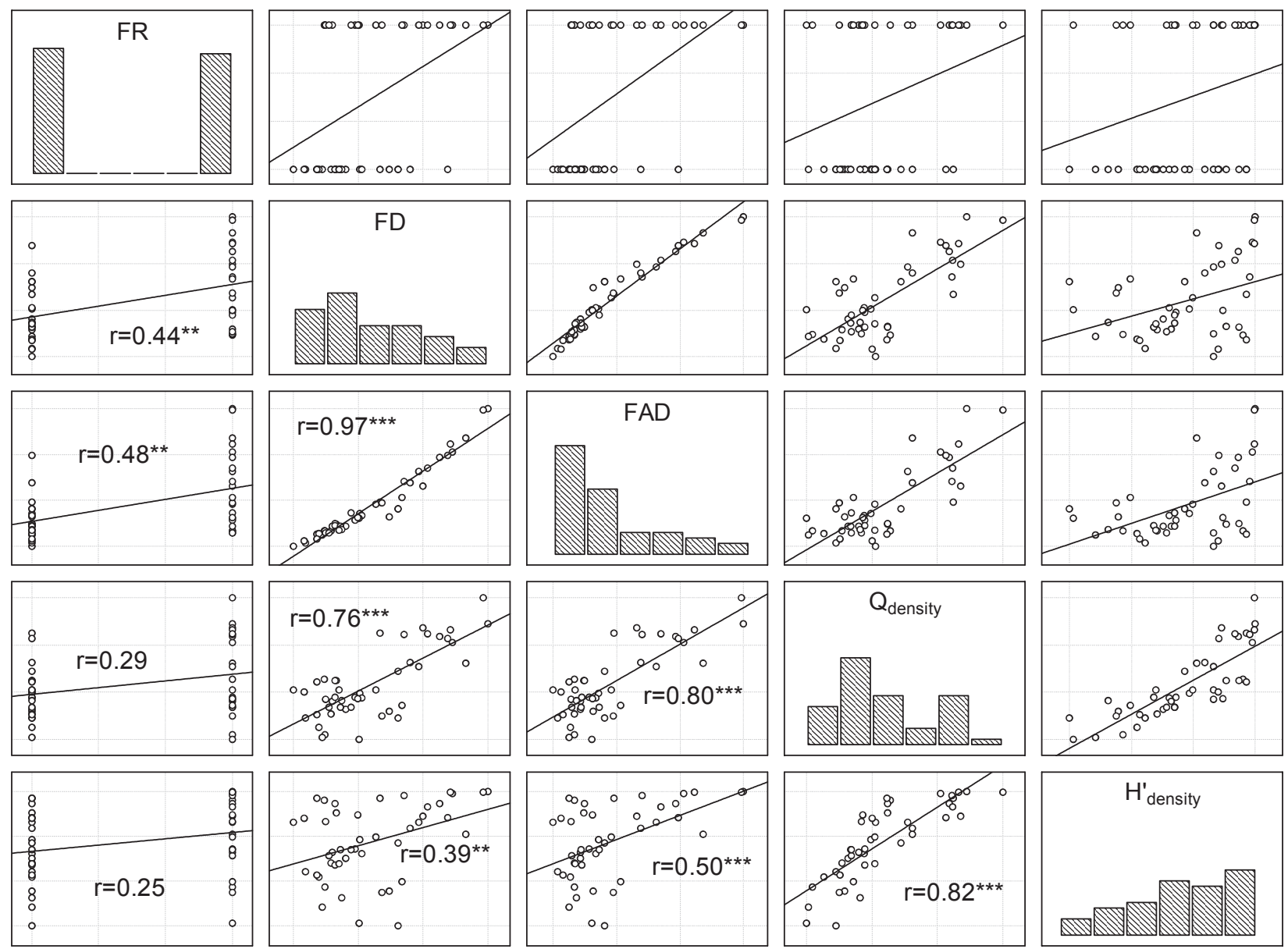

Fig. 3. Correlations between the functional diversity indices for the weed communities developed in spring barley in the spring matrix scatterplot; explanations of the indices in the methodology, $\mathrm{Q}_{\text {density }}, \mathrm{H}_{\text {density }}$ - indices determined on the basis of weed density; $\mathrm{r}-$ simple correlation coefficient, $*-\mathrm{r}$ significant at $\mathrm{p}=0.05, * *-\mathrm{r}$ significant at $\mathrm{p}=0.01$, *** $-\mathrm{r}$ significant at $\mathrm{p}=0.001$. 

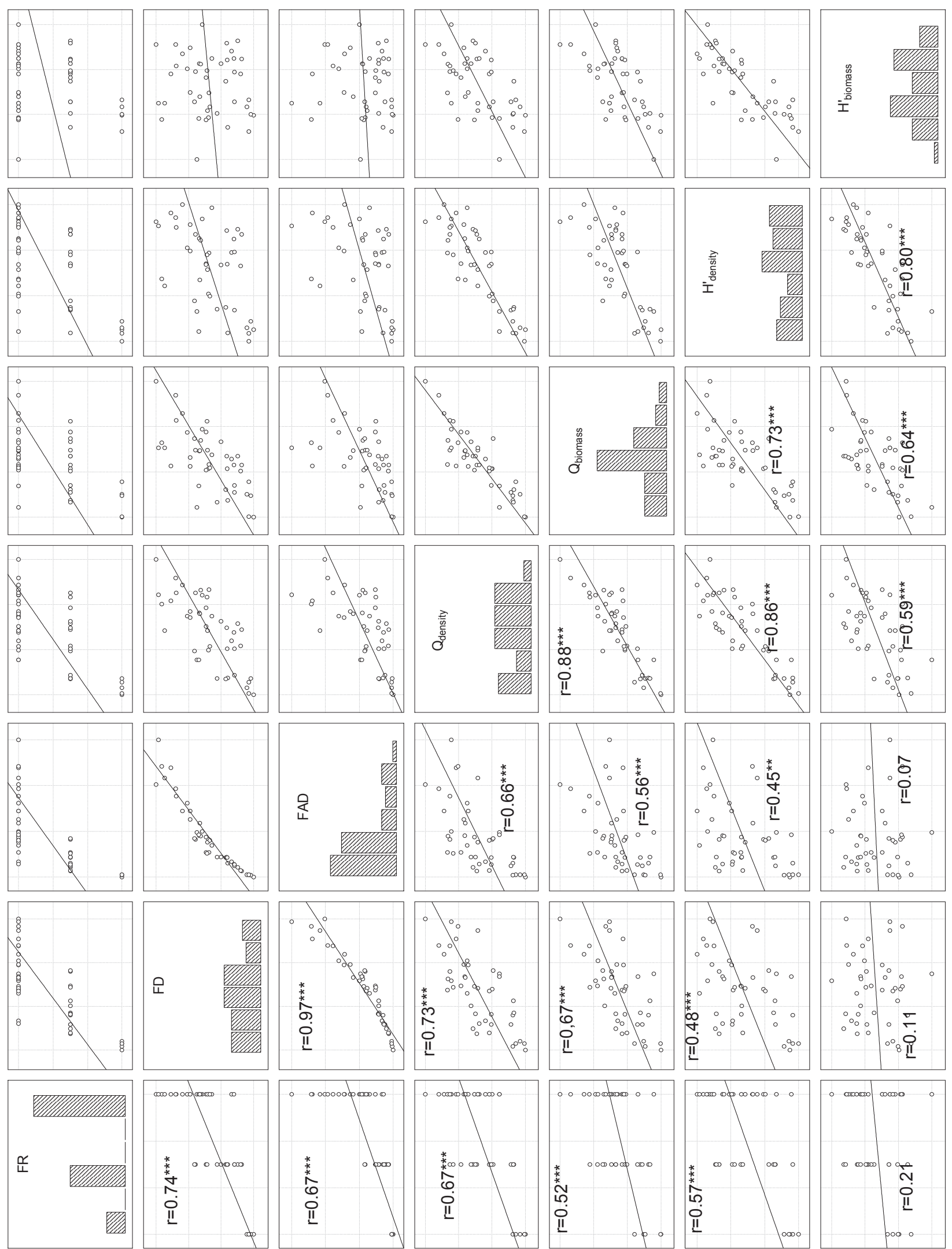

Fig. 4. Correlations between the functional diversity indices for the weed communities developed in spring barley before harvest matrix scatterplot; explanations of the indices in the methodology, $\mathrm{H}_{\text {' }}{ }_{\text {density }}$, $\mathrm{Q}_{\text {density }}$ - indices determined on the basis of weed density, $\mathrm{H}_{\text {'biomass, }}$ Q biomass - indices determined on the basis of weed biomass; $r$ - simple correlation coefficient, ${ }^{*}-\mathrm{r}$ significant at $\mathrm{p}=0.05, * *-\mathrm{r}$ significant at $\mathrm{p}=0.01, * * *-\mathrm{r}$ significant at $\mathrm{p}=0.001$. 
Table 3.

Coefficients of simple correlation between the weed functional diversity indices, on the one hand, and precipitation and temperature over the study period, on the other hand

\begin{tabular}{|c|c|c|c|c|c|c|c|}
\hline \multirow{4}{*}{ Index } & \multirow{4}{*}{$\begin{array}{c}\text { Precipitation } \\
\text { and temperature }\end{array}$} & \multicolumn{6}{|c|}{ Months } \\
\hline & & IV & $\mathrm{V}$ & $\mathrm{VI}$ & VII & VIII & IV-VIII \\
\hline & & \multicolumn{6}{|c|}{ Time of determination } \\
\hline & & spring & & & fore harvest & & \\
\hline \multirow{2}{*}{ FR } & $P$ & 0.25 & 0.42 & $0.55^{*}$ & 0.33 & 0.06 & $0.67 * *$ \\
\hline & $\mathrm{T}$ & -0.44 & 0.10 & -0.36 & -0.43 & $-0.72 * *$ & $-0.65 * *$ \\
\hline \multirow{2}{*}{ FD } & $\mathrm{P}$ & $0.54 *$ & 0.47 & 0.43 & 0.09 & 0.16 & 0.51 \\
\hline & $\mathrm{T}$ & -0.22 & 0.12 & -0.05 & -0.41 & $-0.80 * * *$ & $-0.55 * *$ \\
\hline \multirow{2}{*}{ FAD } & $\mathrm{P}$ & $0.34 *$ & 0.50 & 0.46 & -0.00 & -0.01 & 0.42 \\
\hline & $\mathrm{T}$ & -0.15 & 0.06 & 0.10 & -0.33 & $-0.72 * *$ & -0.51 \\
\hline \multirow{2}{*}{$Q_{\text {density }}$} & $\mathrm{P}$ & $0.67 * *$ & 0.01 & 0.48 & 0.33 & 0.037 & $0.60 *$ \\
\hline & $\mathrm{T}$ & -0.05 & 0.14 & -0.36 & $-0.78 * * *$ & $-0.73 * *$ & $-0.69 * *$ \\
\hline \multirow{2}{*}{$\mathrm{Q}_{\text {biomass }}$} & $\mathrm{P}$ & $\mathrm{x}$ & -0.01 & 0.37 & 0.22 & 0.32 & 0.47 \\
\hline & $\mathrm{T}$ & $\mathrm{x}$ & 0.04 & -0.17 & $-0.63 *$ & $-0.71 * *$ & $-0.62 *$ \\
\hline \multirow{2}{*}{$\mathrm{H}_{\text {density }}$} & $\mathrm{P}$ & 0.37 & 0.18 & 0.41 & 0.36 & 0.19 & 0.51 \\
\hline & $\mathrm{T}$ & -0.35 & -0.13 & -0.48 & $-0.75 * * *$ & -0.53 & $-0.84 * * *$ \\
\hline \multirow{2}{*}{$\mathrm{H}_{\text {biomass }}^{\prime}$} & $\mathrm{P}$ & $\mathrm{x}$ & 0.21 & 0.32 & 0.33 & 0.14 & 0.43 \\
\hline & $\mathrm{T}$ & $\mathrm{x}$ & -0.34 & -0.27 & $-0.67 * *$ & -0.38 & $-0.75 * * *$ \\
\hline
\end{tabular}

$\mathrm{P}$ - precipitation, $\mathrm{T}-$ temperature $; *$ - correlation significant at $\mathrm{p}=0.05, * *$ - correlation significant at $\mathrm{p}=0.01, * * *-$ correlation significant at $=0.001 ; \mathrm{x}$ - no determinations were made; explanations of the indices in the methodology, $\mathrm{H}_{\text {density }}, \mathrm{Q}_{\text {density }}-$ indices determined on the basis of weed density, $\mathrm{H}^{\prime}$ biomass, $\mathrm{Q}_{\text {biomass }}$ - indices determined on the basis of weed density

\section{DISCUSSION}

The concept of functional diversity is gaining more and more importance in world ecological research (Naeem, 2002; Petchey and Gaston, 2006). This induces researchers to include functional diversity in the scope of interest of weed ecology (L e m e r le et al. 2004; P u r i ce 11 i and T u e s c a, 2005; S t or key, 2006; S ingh et al. 2008), but it has not yet been reflected in the national agricultural literature. The world literature draws attention to the need to conduct research on functional diversity of weed associations, highlighting their importance in the maintenance of biodiversity accompanying agrophytocenoses, connected with them by trophic chains (Marshall et al. 2003; S torkey, 2006). On the other hand, the researchers stress the possibility of reducing weed control costs and facilitating weed management through the development of tactics applied to functional groups instead of single species (Le merle et al. 2004). Research is also ongoing on the relationship between various biodiversity components and productivity in plant communities ( $\mathrm{J}$ i a n g et al. 2007).

This present paper merely highlights these issues. The authors' intention was that this paper should become an example - an encouragement for the community of Polish herbologists and phytosociologists to look in the direction of functional diversity. It may be an incentive to search for more effective methodological solutions than those presented here. Therefore, a discussion going in this direction seems to be more advisable than a discussion on the obtained results, since it is still difficult to find any appropriate points of reference in the literature.

The most difficult and most controversial stage of the research on weed functional diversity is the selection of traits determining the classification of species into functional groups. No strict rules have been developed to handle this problem, but valuable guidelines, helpful in making methodological decisions, can be found in some papers (Petchey and Gaston, 2002; Le p š et al. 2006). Trait selection largely depends on the type of process (processes) in the ecosystem or its functions from the point of which species in a group can be classified as interchangeable.

In the case of plant communities, the first and most frequently suggested trait to be used in the classification into functional groups has been the life form, usually following the classification system of Raunkiaer (L a v ore 1 et al. 1997). It can also be used with respect to weeds (S in gh et al. 2008). Weed species can be classified into functional groups according to, for example, their biological traits (seed dormancy or shedding), their phenological stage at the time of assessment (germination, initial growth, flowering, or seed development), their response to agricultural practices or association with a crop species or a group of crop plants (L e m e r l e et al. 2004). Plant protection often classifies weeds in two wide groups: narrow 
leaf weeds (grasses) and broad leaf weeds, taking into account their selective response to active substances (H awe s et al. 2005). S torkey (2006) classified 21 field weed species found in the United Kingdom into functional groups on the basis of several eco-physiological parameters, such as seed weight, initial green area at emergence, relative growth rate (RGR), root weight ratio (RWR) specific leaf area (SLA), maximum height, number of days from emergence to flowering and maturity.

In the present study, functional groups were distinguished on the basis of three arbitrarily selected traits associated with biological form, trophic requirements, and the average height achieved relative to the cereal crop. They seem to be important from the point of view of weed competitiveness, and information on them is easily available in the national literature for all localized species. We leave open the issue of the justification of trait selection. Multidimensional statistical methods are helpful in the classification of species into functional groups (P e tchey and Gaston, 2002), and this has been used in the present paper. However, it is worth pointing out that too large a number of traits can make a clear classification difficult or even reduce functional diversity to species diversity.

Irrespective of trait selection, functional diversity is expressed by means of various measures the number of which is growing in the literature of the subject ( $\mathrm{M}$ a s o n et al. 2003; M o u c h e t et al. 2010; $\mathrm{Schleuter}$ et al. 2010). There is still an ongoing discussion on their usefulness ( $\mathrm{M}$ a s o $\mathrm{n}$ et al. 2003; $\mathrm{Schleuter}$ et al. 2010) and calculation methods (Ricotta, 2005; Petchey and Gaston, 2006). Petchey and Gaston (2006) express an opinion that there is no perfect measure, nor is there likely to be. But they emphasise that it is important to define expectations with respect to such a measure. $\mathrm{M}$ a s o $\mathrm{n}$ et al. (2003) present as many as ten criteria which an index of functional diversity should meet, not counting the fact that it should also reflect the abundance of the species. The study of M o u c het et al. (2010) prove the convergence of several of the indices under evaluation, including FAD, FD, and Q, which was also confirmed in the present study.

\section{CONCLUSIONS}

1. Potato/barley crop rotation with a $25 \%$ share of barley and growing barley once and twice after the same barley crop did not differentiate weed functional biodiversity.

2. The functional diversity indices showed different variations over time. Higher variation was usually observed for the indices calculated for the summer communities than for the spring ones.
3 . The strength and significance of the positive correlation between weed functional diversity and precipitation in the growing season and of the negative correlation with mean temperature for the period from April to August were dependent on the measure of diversity.

4. The functional diversity indices showed high convergence. The FD and FAD indices proved to be interchangeable.

5. The justification for the use of functional diversity indices in the assessment of field weed communities should be validated by further research.

\section{Acknowledgements:}

Research supported by Poland's Ministry of Science and Higher Education as part of the statutory activities of the Department of Agricultural Systems, University of Warmia and Mazury in Olsztyn.

\section{REFERENCES}

Biswas S.R., Mallik A.U., 2010. Disturbance effects on species diversity and functional diversity in riparian and upland plant communities. Ecology, 91(1): 28-35.

Blecharczyk A., Małecka I., Skrzypczak G., 2000. Wpływ wieloletniego nawożenia, zmianowania i monokultury na zachwaszczenie jęczmienia jarego. / Effect of long-term fertilization, crop rotation and continuous cropping on weed infestation of spring barley. Ann. UMCS, Sect. E, 55, suppl.: 17-23 (in Polish).

de Bello F., Lepš J., Sebastír M.-T., 2006. Variations in species and functional plant along climatic and grazing gradients. Ecography, 29: 801-810.

Devin S., Beisel J.N., Usseglio-Polatera P., Moreteau J.C., 2005. Changes in functional biodiversity in an invaded freshwater ecosystem: the Moselle River. Hydrobiologia, 542: 113-120

Diaz S., Cabido M., 2001. Vive la différence: plant functional diversity matters to ecosystem processes. Trends Ecol. Evol. 16: 647-655.

Domańska H., 1997. Chwasty. [In:] Ogólna uprawa roli i roślin W. Roszak (ed.). Wyd. Nauk. PWN, Warszawa: 119-194. (in Polish)

E1ton C., 1927. Animal ecology. McMillan, New York.

Feledyn-Szewczyk B., 2008. The changes of biodiversity of weed flora in organic system in the years 19962007. J. Res. Appl. Agric. Eng. 53: 63-68.

Hawes C., Begg G.S., Squire G.R., Iannetta P.P.M., 2005. Individuals as the basic according unit in studies of ecosystem function: functional diversity in shepherd's purse, Capsella: Oikos, 109: 521-534.

Hooper D.U., Solan M., Symstad A., Diaz S., Gessner M.O., Buchmann N., Degrange V., Grime P., Hulot F., Mermillod-Blondin F., Roy J., Spehn E., Van Peer L., 2002. Species diversity, functional diversity, and ecosystem 
functioning. [In:] Biodiversity and ecosystem functioning. Synthesis and Perspectives. M. Loreau, S. Naeem, P. Inchausti (eds.). Oxford University Press: 195-281.

Jastrzębska M., Wanic M., Kostrzewska M.K., Nowicki J., 2006. Biological diversity of cereal fields. Pol. J. Natur. Sc. 12: 499-518.

Jędruszczak M., Antoszek R., 2004. Sposoby uprawy roli a bioróżnorodność zbiorowisk chwastów w monokulturze pszenicy ozimej. / Tillage systems and biodiversity of weed communities in winter wheat monoculture. Acta Sci. Pol., Agricult. 3: 47-59 (in Polish).

Jiang X.L., Zhang W.G., Wang G., 2007. Effects of different components of diversity on productiviry in artificial plant communities. Ecol. Res. 22: 625-634.

Kaar B., Freyer B., 2008. Weed species diversity and cover-abundance in organic and conventional winter cereal fields and 15 years ago. 2nd Conference of the International Society of Organic Agriculture Research ISOFAR, June 18-20, 2008, Modena, Italy, Archived at http://orgprints.org/view/projects/conference.html

Lavorel S., McIntyre S., Landsberg J., Forbes T.D.A., 1997. Plant functional classifications: from general group to specific group based on response to disturbance. Trends Ecol. Evol. 12: 474-478.

Lemerle D., Storrie A., Panetta F.D., 2004. The potential role of weed functional group in cropping systems. In: Weed management: balancing people, planet, profit. 14th Australian Weeds Conference, Wagga Wagga, New South Wales, Australia, 6-9 September 2004: papers and proceedings: 133-135.

Lepš J., de Bello F., Lavorel S., Berman S., 2006. Quantifying and interpreting functional diversity of natural communities: practical considerations matter. Preslia, 78: 481-501

Lososová Z., Chytrý M., Cimalová Š., Kropáč Z., Otýpková Z., Pyšek P., Tichý L., 2004. Weed vegetation of arable land in Central Europe: gradients of diversity and species composition. J. Veg. Sci. 15: 415-422.

Magurran A., 2005. Measuring Biological Diversity. Blackwell Science, Oxford.

Marshall E.J.P., Brown V.K, Boatman N.D., Lutman P.J., Squire G.R. Ward L.K., 2003. The role of weeds in supporting biological diversity within crop fields. Weed Res. 43(2): 77-89.

Mason N.W.H., Macgillivray K., Steel J.B., Wils on J.B., 2003. An index of functional diversity. J. Veg. Sci. 14: 571-578.

Mirek Z., Piękoś-Mirek H., Zając A., Zając M., 1995. Vascular plants of Poland a checklist. Instytut Botaniki im. W. Szafera w Krakowie, PAN.

Mouchet M.A., Ville'ger S., Mason N.W.H., Mouillot D., 2010. Functional diversity measures: an overview of their redundancy and their ability to discriminate community assembly rules. Funct. Ecol. 24: 867-876.
Na e e m S ., 2002. Disentangling the impacts of diversity on ecosystem functioning in combinatorial experiments. Ecology, 83: 2925-2935.

Petchey O.L., Gaston K.J., 2002. Functional diversity (FD), species richness and community composition. Ecol. Lett. 5: 402-411.

Petchey O.L., Gaston K.J., 2006. Functional diversity: back to basics and looking forward. Ecol. Lett. 9: 741-758.

Puricelli E., Tuesca D., 2005. Weed density and diversity under glyphosate-resistant crop sequences. Crop Prot. 24: 533-542.

R a o C.R., 1982. Diversity and dissimilarity coefficients a unified approach. Theor. Popul. Biol. 21: 24-43.

Ric otta C., 2005. A note on functional diversity measures. Basic Appl. Ecol. 6: 479-486.

Schleuter D., Daufresne M., Massol F., Argillier C., 2010. A user's guide to functional diversity indices. Ecol. Monogr. 80(3): 469-484.

Scrosati R.A., Genne B. van, Heaven C.S., Watt C.A., 2010. Species richness and diversity in different functional groups across environmental stress gradients: a model for marine rocky shores. Ecography, 33: $1-25$.

Shannon C.E., 1948. A mathematical theory of communication. The Bell System Techn. J., 27: 379-423.

Singh A., Sharma G.P., Raghubanshi A.S., 2008. Dynamics of the functional group in the weed flora of dryland and irrigated agroecosystems in the Gangetic plains of India. Weed. Biol. Manag. 8: 250-259.

Stevenson F.C., Légčre A., Simard R.R., Angers D.A., Pageau D., Lafond J., 1997. Weed species diversity in spring barley varies with crop rotation and tillage, but not with nutrient source. Weed Sci. 45: 798-806.

St orkey J., 2006. A functional group approach to the management of UK arable weeds to support biological diversity. Weed Res. 46: 513-522.

Tilman D., 2001. Functional diversity. [In:] Encyclopedia of Biodiversity S.A. Levin (ed.). Academic Press, San Diego, A: 109-120.

Walker B., Kinzig A.P., Langride J., 1999. Plant attribute diversity, resilience, and ecosystem function: the nature and significance of dominant and minor species. Ecosystems, 2: 95-103.

Walker B.H., Langridge J.L., 2002. Measuring functional diversity in plant communities with mixed life forms: a problem of hard and soft attributes. Ecosystems, 5: 529-538.

Wanic M., Jastrzębska M., Kostrzewska M.K., 2010. Influence of crop rotation and meteorological conditions on density and biomass of weeds in spring barley (Hordeum vulgare L.). Acta Agrobot. 63(1): 213-220.

Wiener N., 1948. Cybernetics, or control and communication in the animal and the machine. The MIT Press, Cambridge, MA, USA. 
Zarzycki K., Trzcińska-Tacik H, Różański W., Szeląg Z., Wołek J., Korzeniak U., 2002. Ecological indicator values of vascular plants of Poland. Instytut Botaniki im. W. Szafera, PAN, Kraków.

\section{Próba zastosowania \\ wskaźników różnorodności funkcjonalnej do oceny zbiorowisk chwastów}

\section{Streszczenie}

$\mathrm{W}$ pracy przedstawiono analizę zmian różnorodności funkcjonalnej chwastów w jęczmieniu jarym uprawianym w latach 1990-2004 w płodozmianie z 25\% udziałem tego zboża (ziemniak - jęczmień jary - groch siewny - pszenżyto ozime) w następstwie po ziemniaku i w płodozmianie z 75\% jego udziałem (ziemniak - jęczmień jary - jęczmień jary - jęczmień jary) w jedno- i dwukrotnym następstwie po sobie. W eksperymencie nie stosowano ochrony przed chwastami. Corocznie, wiosną (w pełni wschodów zboża) i przed zbiorem oznaczano skład gatunkowy i liczebność poszczególnych gatunków chwastów, a przed zbiorem także ich biomasę. Na tej podstawie obliczono wybrane wskaźniki różnorodności funkcjonalnej. W rozdzieleniu chwastów do grup funkcjonalnych oraz ustaleniu niektórych wskaźników wykorzystano techniki wielowymiarowe. Następstwo jęczmienia po ziemniaku w płodozmianie z $25 \%$ udziałem jęczmienia oraz jedno- i dwukrotne jego następstwo po sobie nie różnicowało różnorodności funkcjonalnej chwastów.

Wskaźniki różnorodności funkcjonalnej chwastów wykazywały zróżnicowaną zmienność w czasie. Większą zmienność notowano zwykle w ramach wskaźników liczonych dla zbiorowisk letnich, niż wiosennych. Siła i istotność dodatniej korelacji różnorodności funkcjonalnej chwastów z ilością opadów za okres wegetacji oraz ujemnej ze średnią temperaturą w okresie od kwietnia do sierpnia kształtowały się zależnie od miernika różnorodności. Wskaźniki różnorodności funkcjonalnej wykazywały dużą zbieżność. Wzajemnie zastępowalne okazały się wskaźniki FD i FAD. 